\title{
Application of ultrasonic testing method for determining defects of hot-deformed powder materials
}

\author{
Maxim S. Egorov ${ }^{1,1}$, Andrey A. Atrokhov ${ }^{1}$, Evgeniy A. Nedostup ${ }^{1}$, and Ekaterina $V$. \\ Vasilyeva $^{1}$ \\ ${ }^{1}$ Don state technical University, Rostov-on-don, Russia
}

\begin{abstract}
The article is devoted to the analysis of elastic and plastic characteristics of composite materials during hot stamping. The purpose of this work is to offer optimal conditions for hot plasticity of composite porous material with determination of temperature conditions of hot stamping excluding the appearance of defects in the structure. Production of details of the difficult form by method of hot stamping from preparations of the cylindrical form is followed by development of barrel on a peripheral surface. Sludge sintered porous blanks, and sediment compact material, accompanied by a nonuniform height lateral deformation. In connection with the action of friction forces on the contact surfaces, this leads to the formation of a "barrel". The heterogeneity of the deformed state is associated with the appearance of tangential tensile stresses on the free surface of the workpiece. If they exceed some critical degree of transverse deformation, cracks appear on the side surface, which leads to gas saturation (oxidation) of the inner layers of the forging, to the ingress of grease into them and its pressing into the volume of the part during hot stamping. In the end, this significantly reduces the properties of hot-stamped parts. Conclusion: the methods of determining the elastic characteristics depending on the geometric parameters of the workpieces, the applied strain energy, body density and temperature dependence of the plasticity characteristics of the hot deformation of the powder material are considered.
\end{abstract}

The problem of non-destructive testing of structural materials in actual condition is very relevant, because defects and changes in the structure of the material arising in the manufacture and operation of products can significantly reduce their strength. Elastic modulus - the most important characteristics of a rigid body. They are the design parameters in the analytical apparatus of the physical theory of deformation and fracture of a solid, are included in all the fundamental equations of mechanics.

The values of the elastic modulus and Poisson's ratio of even pure substances-elements and chemical compounds of constant composition, determined on materials of different purity by different methods - are very different, which indicates their lack of reliability.

\footnotetext{
${ }^{1}$ Corresponding author: aquavdonsk@mail.ru
} 
This applies even more to sintered composite materials, which have very developed discontinuities - pores.

It should be noted that there is very little information in the literature about changes in the elastic characteristics of sintered materials depending on their porosity. Some of them are devoted to theoretical methods for determining the elastic modulus and Poisson's ratio [1], and some - experimental [2,3].

Currently, ultrasonic vibrations are used to study the elastic and inelastic characteristics of solid sintered porous materials. In particular, the ultrasonic method of testing the strength and homogeneity of the material is based on the principle of measuring the speed of the ultrasonic pulse, the value of which depends on the elastic properties and density of the material.

In this paper, an ultrasonic echo - pulse method based on the measurement of the passage time of the ultrasonic signal in a freely deposited sintered sample is used. The following equipment was used: universal thickness gauge Krautkramer DMS 2 - measures the longitudinal velocity of the ultrasonic wave and flaw detector Krautkramer USM 25 measures the transverse velocity of the ultrasonic wave. Glycerin was used as a contact lubricant. The results of measurements of velocities $\mathrm{v}_{l}$ and $\mathrm{v}_{t}$ in the samples are listed in table. 1 using table values.3.

Table 1. Density $\rho_{\text {medium }}$ and sample height $h_{\kappa}$ after dynamic hot pressing

\begin{tabular}{|c|c|c|c|c|}
\hline $\begin{array}{l}\text { Sample } \\
\text { number }\end{array}$ & $w,{ }^{M J} / m^{3}$ & $\begin{array}{c}\text { Source } \\
\text { material }\end{array}$ & $\rho_{\text {medium }}, x 10^{3} \mathrm{~kg} / \mathrm{m}^{3}$ & $h_{k}, m m$ \\
\hline 1.30 & 70 & \multirow{3}{*}{ Astaloy $0,85 \mathrm{Mo}$} & 6,16 & 8 \\
\hline 1.20 & 80 & & 6,99 & 7,5 \\
\hline 1.10 & 135 & & 7,3 & 5,6 \\
\hline 2.30 & 75 & \multirow{3}{*}{ Distaloy HP-1 } & 6,09 & 8,7 \\
\hline 2.20 & 86 & & 6,96 & 7,5 \\
\hline 2.10 & 150 & & 7,11 & 6 \\
\hline 3.30 & 80 & \multirow{3}{*}{$\mathrm{ABC} 100.30$} & 6,5 & 7,4 \\
\hline 3.20 & 92 & & 7,03 & 6,9 \\
\hline 3.10 & 150 & & 7,4 & 5,3 \\
\hline 4.30 & 72 & \multirow{3}{*}{ NC 100.24} & 6,17 & 8 \\
\hline 4.20 & 75 & & 6,93 & 7,7 \\
\hline 4.10 & 130 & & 7,3 & 5,9 \\
\hline
\end{tabular}

The experimental values of the mean density of the deposited samples are shown in table 1., which are observed on the Astaloy 0.85 Mo microstructure (Fig. 1). So on the periphery, there are microexplosion at interparticle boundaries (Fig. 1 b). The Central zone (Fig. 1 a) differs from the peripheral region (Fig. 1 b) by a smaller accumulation of microplanes. 


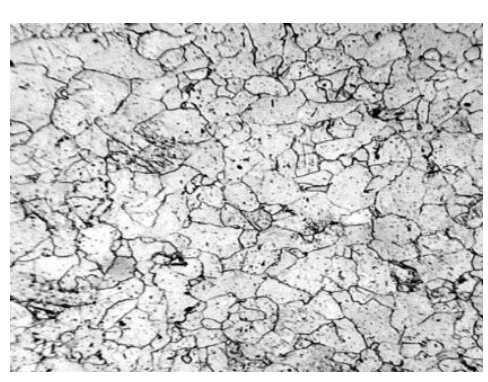

$a$

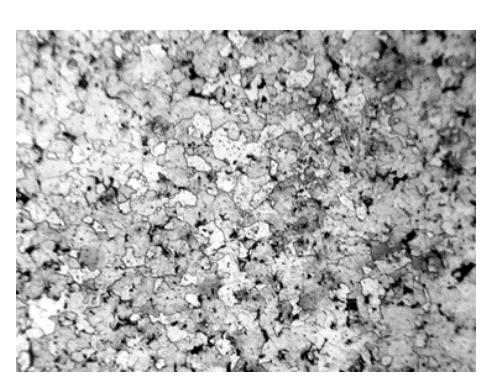

$b$

Fig. 1. a) Microstructure Of Astaloy 85 Mo the Central zone. b) Microstructure of Astaloy 85 Mo peripherals

Method determining the values of $\mathrm{v}_{l}$ and $\mathrm{v}_{t}$ is determined by the formulas

$$
\begin{aligned}
& \mathrm{v}_{l}=2 \cdot l \cdot \Delta f_{x}\left[1+\rho_{s} \cdot l_{s} /\left(\rho_{0} \cdot l_{0}\right)\right] \\
& \mathrm{v}_{t}=2 \cdot l \cdot \Delta f_{y}\left[1+\rho_{s} \cdot l_{s} /\left(\rho_{0} \cdot l_{0}\right)\right]
\end{aligned}
$$

$\rho_{s}, \rho_{0}$ - density of quartz sensor and sample;

$l_{s}, l_{0}$ - quartz sensor and sample lengths;

$\Delta f_{x}, \Delta f_{y}$ - average frequency differences between neighboring harmonics.

The elastic modulus was determined by the relations $[1,3,4]$

$$
\begin{gathered}
E=2 G \cdot(1+\mu) \\
G=\rho \cdot \mathrm{v}_{t}^{2} \\
K=\frac{E}{3 \cdot(1-2 \cdot \mu)} \\
\mu=\frac{1-0,5 \cdot\left(\mathrm{v}_{l} / \mathrm{v}_{t}\right)^{2}}{1-\left(\mathrm{v}_{l} / \mathrm{v}_{t}\right)^{2}}
\end{gathered}
$$

The maximum relative error in determining the young's modulus in the applied opticalacoustic method is $\delta E=6 \%$

The maximum relative error in determining the Jung's modulus in the applied opticalacoustic method is $\delta E=6 \%$, the shear modulus $-\delta G=4 \%$, the Poisson's ratio $-\delta \mu=$ $5 \%$.

As a test sample with known values of elastic modules, an aluminum sample (density $\rho=2,69 \cdot 10^{3} \mathrm{~kg} / \mathrm{m}^{3}$, thickness $H=7,3 \mathrm{~mm}$ ) was studied. The results of ultrasonic measurements for this sample and reference data for aluminum [2] are given in Table 2.

Table 2. Compliance of measurement results with reference data.

\begin{tabular}{|c|c|c|c|c|}
\hline $\mathrm{v}_{l} \cdot 10^{3} \mathrm{~m} / \mathrm{s}$ & $\mathrm{v}_{t} \cdot 10^{3} \mathrm{~m} / \mathrm{s}$ & $E, G P a$ & $G, G P a$ & $\mu$ \\
\hline \multicolumn{5}{|c|}{ Reference data } \\
\hline 6,26 & 3,08 & $69-72$ & $25-26,5$ & $0,31-0,33$ \\
\hline \multicolumn{5}{|c|}{ Results of optoacoustic measurements } \\
\hline $6,28 \pm 0,03$ & $3,13 \pm 0,05$ & $70,5 \pm 3,9$ & $26,4 \pm 0,9$ & $0,340 \pm 0,33$ \\
\hline
\end{tabular}


The results of measurements of the phase velocities of longitudinal and shear ultrasonic waves, as well as calculated by the formulas (1-6) values of Jung's modulus, shear and Poisson's ratio, as well as porosity values in the center $(\mathrm{C})$ and periphery $(\mathrm{P})$ of all studied samples are presented in Table 3. Determination of the bulk porosity $\mathrm{R}$ from theoretical calculated and experimentally measured values of longitudinal ultrasonic wave velocities $[1,5,6]$ in the studied areas of the samples gives the values presented in Table 3.

Table 3 Results of ultrasonic measurements of samples from powder materials

\begin{tabular}{|c|c|c|c|c|c|c|c|c|c|c|c|c|c|}
\hline \multirow[t]{2}{*}{ ample ${ }^{*}$} & \multirow[t]{2}{*}{$\begin{array}{c}\mathrm{W}, \\
\mathrm{MJ} / \mathrm{m}^{3}\end{array}$} & \multicolumn{2}{|c|}{$\begin{array}{c}\text { Velocity of } \\
\text { longitudinal } \\
\mathrm{UW} \\
v_{l}, \times 10^{3} \\
\mathrm{~m} / \mathrm{s}\end{array}$} & \multicolumn{2}{|c|}{$\begin{array}{c}\text { Speed of } \\
\text { transverse } \\
\text { UW } \\
v_{t}, \times 10^{3} \\
\mathrm{~m} / \mathrm{s}\end{array}$} & \multicolumn{2}{|c|}{$\begin{array}{l}\text { Young's } \\
\text { modulus } \\
E, G P a\end{array}$} & \multicolumn{2}{|c|}{$\begin{array}{c}\text { Shear } \\
\text { modulus } \\
G, G P a\end{array}$} & \multicolumn{2}{|c|}{$\begin{array}{c}\text { Poisson ratio } \\
\mu\end{array}$} & \multicolumn{2}{|c|}{$\begin{array}{l}\text { Porosity, } \\
\text { R, \% }\end{array}$} \\
\hline & & $\mathrm{C}$ & $\mathrm{P}$ & $\mathrm{C}$ & $\mathrm{P}$ & $\mathrm{C}$ & $P$ & C & $\mathrm{P}$ & C & $\mathrm{P}$ & $\mathrm{C}$ & $\mathrm{P}$ \\
\hline 1.30 & 70 & $\begin{array}{c}5,578 \\
\pm \\
0,03\end{array}$ & $\begin{array}{c}5,49 \\
\pm \\
0,03\end{array}$ & $\begin{array}{c}2,75 \\
\pm \\
0,06\end{array}$ & $\begin{array}{c}2,603 \\
\pm \\
0,06\end{array}$ & $\begin{array}{l}117 \\
\pm \\
4,9\end{array}$ & $\begin{array}{l}108 \\
\pm \\
5,1\end{array}$ & $\begin{array}{l}47 \\
\pm \\
1,2\end{array}$ & $\begin{array}{l}40 \\
\pm \\
1,2\end{array}$ & $\begin{array}{c}0,256 \\
\pm \\
0,016\end{array}$ & $\begin{array}{c}0,355 \\
\pm \\
0,016\end{array}$ & 20 & 26 \\
\hline 1.20 & 80 & $\begin{array}{c}5,46 \\
\pm \\
0,03\end{array}$ & $\begin{array}{c}5,56 \\
\pm \\
0,03\end{array}$ & $\begin{array}{c}2,89 \\
\pm \\
0,06\end{array}$ & $\begin{array}{c}2,71 \\
\pm \\
0,06\end{array}$ & $\begin{array}{c}152 \\
\pm \\
5,5\end{array}$ & $\begin{array}{l}128 \\
\pm \\
5,2\end{array}$ & $\begin{array}{l}58 \\
\pm \\
1,3\end{array}$ & $\begin{array}{l}47 \\
\pm \\
1,3\end{array}$ & $\begin{array}{c}0,32 \\
\pm \\
0,016\end{array}$ & $\begin{array}{c}0,344 \\
\pm \\
0,016\end{array}$ & 10 & 17 \\
\hline 1.10 & 135 & $\begin{array}{c}6,07 \\
\pm \\
0,03\end{array}$ & $\begin{array}{l}6 \pm \\
0,03\end{array}$ & $\begin{array}{c}3,14 \\
\pm \\
0,06\end{array}$ & $\begin{array}{c}3,103 \\
\pm \\
0,06\end{array}$ & $\begin{array}{c}189 \\
\pm \\
5,2\end{array}$ & $\begin{array}{l}181 \\
\pm \\
4,9\end{array}$ & $\begin{array}{l}72 \\
\pm \\
1,2\end{array}$ & $\begin{array}{l}68 \\
\pm \\
1,2\end{array}$ & $\begin{array}{c}0,316 \\
\pm \\
0,016\end{array}$ & $\begin{array}{c}0,314 \\
\pm \\
0,016\end{array}$ & 6 & 8 \\
\hline 2.30 & 75 & $\begin{array}{c}5,58 \\
\pm \\
0,03\end{array}$ & $\begin{array}{c}5,36 \\
\pm \\
0,03\end{array}$ & $\begin{array}{c}2,64 \\
\pm \\
0,06\end{array}$ & $\begin{array}{c}2,49 \\
\pm \\
0,06\end{array}$ & $\begin{array}{l}96 \\
\pm \\
4,9\end{array}$ & $\begin{array}{l}95 \\
\pm \\
5,2\end{array}$ & $\begin{array}{l}48 \\
\pm \\
1,3\end{array}$ & $\begin{array}{l}35 \\
\pm \\
1,3\end{array}$ & $\begin{array}{c}0,356 \\
\pm \\
0,016\end{array}$ & $\begin{array}{c}0,362 \\
\pm \\
0,016\end{array}$ & 22 & 27 \\
\hline 2.20 & 86 & $\begin{array}{c}5,44 \\
\pm \\
0,03\end{array}$ & $\begin{array}{c}5,4 \\
\pm \\
0,03\end{array}$ & $\begin{array}{c}2,883 \\
\pm \\
0,06\end{array}$ & $\begin{array}{c}2,65 \\
\pm \\
0,06\end{array}$ & $\begin{array}{l}151 \\
\pm \\
4,9 \\
\end{array}$ & $\begin{array}{l}119 \\
\pm \\
4,9\end{array}$ & $\begin{array}{l}58 \\
\pm \\
1,2\end{array}$ & $\begin{array}{l}44 \\
\pm \\
1,2\end{array}$ & $\begin{array}{c}0,32 \\
\pm \\
0,016\end{array}$ & $\begin{array}{c}0,341 \\
\pm \\
0,016\end{array}$ & 10 & 18 \\
\hline 2.10 & 150 & $\begin{array}{c}5,8 \\
\pm \\
0,03\end{array}$ & $\begin{array}{c}5,53 \\
\pm \\
0,03\end{array}$ & $\begin{array}{c}3,123 \\
\pm \\
0,06\end{array}$ & $\begin{array}{c}2,878 \\
\pm \\
0,06\end{array}$ & $\begin{array}{l}182 \\
\pm \\
4,7\end{array}$ & $\begin{array}{l}152 \\
\pm \\
4,7\end{array}$ & $\begin{array}{l}70 \\
\pm \\
1,3\end{array}$ & $\begin{array}{l}58 \\
\pm \\
1,3\end{array}$ & $\begin{array}{c}0,296 \\
\pm \\
0,016\end{array}$ & $\begin{array}{c}0,318 \\
\pm \\
0,016\end{array}$ & 7 & 9 \\
\hline 3.30 & 80 & $\begin{array}{c}5,46 \\
\pm \\
0,03\end{array}$ & $\begin{array}{c}5,44 \\
\pm \\
0,03\end{array}$ & $\begin{array}{c}2,79 \\
\pm \\
0,06\end{array}$ & $\begin{array}{c}2,61 \\
\pm \\
0,06\end{array}$ & $\begin{array}{c}132 \\
\pm \\
5,0\end{array}$ & $\begin{array}{l}109 \\
\pm \\
5,0\end{array}$ & $\begin{array}{l}50 \\
\pm \\
1,2\end{array}$ & $\begin{array}{l}41 \\
\pm \\
1,2\end{array}$ & $\begin{array}{c}0,323 \\
\pm \\
0,016\end{array}$ & $\begin{array}{c}0,351 \\
\pm \\
0,016\end{array}$ & 18 & 24 \\
\hline 3.20 & 92 & $\begin{array}{c}5,9 \\
\pm \\
0,03\end{array}$ & $\begin{array}{c}5,52 \\
\pm \\
0,03\end{array}$ & $\begin{array}{c}3,17 \\
\pm \\
0,06\end{array}$ & $\begin{array}{c}2,73 \\
\pm \\
0,06\end{array}$ & $\begin{array}{c}183 \\
\pm \\
4,9 \\
\end{array}$ & $\begin{array}{l}122 \\
\pm \\
5,0\end{array}$ & $\begin{array}{l}70 \\
\pm \\
1,3\end{array}$ & $\begin{array}{l}45 \\
\pm \\
1,3\end{array}$ & $\begin{array}{c}0,318 \\
\pm \\
0,016\end{array}$ & $\begin{array}{c}0,337 \\
\pm \\
0,016\end{array}$ & 9 & 15 \\
\hline 3.10 & 150 & $\begin{array}{c}6,1 \\
\pm \\
\pm, 03\end{array}$ & $\begin{array}{c}5,985 \\
\pm \\
0,03\end{array}$ & $\begin{array}{c}3,34 \\
\pm \\
0,06\end{array}$ & $\begin{array}{c}3,225 \\
\pm \\
0,06\end{array}$ & $\begin{array}{c}210 \\
\pm \\
4,7\end{array}$ & $\begin{array}{c}199 \\
\pm \\
5,1\end{array}$ & $\begin{array}{l}82 \\
\pm \\
1,2\end{array}$ & $\begin{array}{l}77 \\
\pm \\
1,2\end{array}$ & $\begin{array}{c}0,286 \\
\pm \\
0,016\end{array}$ & $\begin{array}{c}0,296 \\
\pm \\
0,016\end{array}$ & 4,5 & 5,5 \\
\hline 4.30 & 72 & $\begin{array}{c}5,96 \\
\pm \\
\pm 0,03\end{array}$ & $\begin{array}{c}5,5 \\
\pm \\
0,03\end{array}$ & $\begin{array}{c}2,7 \\
\pm \\
0,06\end{array}$ & $\begin{array}{c}2,605 \\
\pm \\
0,06\end{array}$ & $\begin{array}{c}123 \\
\pm \\
4,9\end{array}$ & $\begin{array}{c}108 \\
\pm \\
4,9\end{array}$ & $\begin{array}{l}44 \\
\pm \\
1,3\end{array}$ & $\begin{array}{l}40 \\
\pm \\
1,3\end{array}$ & $\begin{array}{c}0,371 \\
\pm \\
0,016\end{array}$ & $\begin{array}{c}0,353 \\
\pm \\
0,016\end{array}$ & 19,5 & 25,6 \\
\hline 4.20 & 75 & $\begin{array}{c}5,9 \\
\pm \\
0,03\end{array}$ & $\begin{array}{c}5,5 \\
\pm \\
0,03\end{array}$ & $\begin{array}{c}2,897 \\
\pm \\
0,06\end{array}$ & $\begin{array}{c}2,71 \\
\pm \\
0,06\end{array}$ & $\begin{array}{c}156 \\
\pm \\
5,1\end{array}$ & $\begin{array}{c}120 \\
\pm \\
4,7\end{array}$ & $\begin{array}{l}58 \\
\pm \\
1,3\end{array}$ & $\begin{array}{l}45 \\
\pm \\
1,3\end{array}$ & $\begin{array}{c}0,32 \\
\pm \\
0,016\end{array}$ & $\begin{array}{c}0,339 \\
\pm \\
0,016\end{array}$ & 10 & 16 \\
\hline 4.10 & 130 & $\begin{array}{c}6,05 \\
\pm \\
0,03\end{array}$ & $\begin{array}{c}5,98 \\
\pm \\
0,03\end{array}$ & $\begin{array}{c}3,28 \\
\pm \\
0,06\end{array}$ & $\begin{array}{c}3,180 \\
\pm \\
0,06\end{array}$ & $\begin{array}{c}202 \\
\pm \\
5,1\end{array}$ & $\begin{array}{c}150 \\
\pm \\
4,8\end{array}$ & $\begin{array}{l}78 \\
\pm \\
1,2\end{array}$ & $\begin{array}{l}58 \\
\pm \\
1,2\end{array}$ & $\begin{array}{c}0,292 \\
\pm \\
0,016\end{array}$ & $\begin{array}{c}0,297 \\
\pm \\
0,016\end{array}$ & 5,7 & 7,4 \\
\hline
\end{tabular}

* Samples with visually absent defects of the peripheral region were selected for analysis, it was assumed that they are borderline. In numbering, the first digit indicates the brand of powder from which the sample is made, and the second, after the point-the initial porosity. 
The distribution and propagation velocity of ultrasonic waves are higher, the denser the material in the Central zone, and the decompression observed at the periphery causes lower velocities of ultrasonic waves, which indicates a large number of micro-and macro-defects formed by channel connections of pores in the places of deformation flow of the material. However, the obtained values of the longitudinal velocities in the center and at the periphery indicate an uneven distribution of the density of the deformable material in the volume of the test sample.

Thus, the experimentally implemented ultrasonic method for measuring local elastic modules of samples of isotropic solids allows non-destructive measurements of elastic modules in samples $0.1-70 \mathrm{~mm}$ thick with a locality in the transverse direction of 1-2 $\mathrm{mm}$. At the same time, the maximum relative error in determining the Jung's modulus in the applied optoacoustic method is $\delta E=6 \%$, the shear modulus - $\delta G=4 \%$, the Poisson's ratio $-\delta \mu=5 \%$ even for highly ultrasound - absorbing samples.

The ultrasonic method makes it possible to measure the local values of elastic modules of inhomogeneous solids, in cases where the classical methods of control are difficult to perform, since the manufacture of samples of complex figured shape with high porosity is difficult.

The realized ultrasonic method allows to carry out nondestructive local diagnostics of mechanical and acoustic properties of composite materials on the actual state. Such diagnostics is necessary at the stage of working out and improvement of technology of production of material, and also for identification of "weak" places with smaller durability in material before production of details and products.

Analysis of the results allows us to conclude that the obtained values of the elastic modulus confirm the uneven distribution of the density of powder materials. Comparing the values of the elastic modulus of the Central and peripheral zones of the studied samples, it should be noted the nonlinear nature of the distribution of the deformable material in the volume of the studied sample.

\section{References}

1. R. V. Egorova, M. S. Egorov, A.V. Skorikov. Free sediment heated cylindrical samples of powder materials ASTALOY 85 MO, DISTALOY HP-1 firm "Höganäs" / I metallurg.- 2013.- No. 5.- P. 82-86.

2. R. V. Egorova, M. S. Egorov, V. N. Pustovoit. Hardening of powder materials in the measurement of hot hardness / / Hardening technologies and coatings. - 2018. - No. 4 (160). P. 157-160.

3. M. S. Egorov, R. V. Egorova et al. Structure and properties of materials made of powder materials after their plastic deformation // in the collection: Science in Russia: promising research and development collection of materials I all-Russian scientificpractical conference. -2017. - P. 131-137.

4. R. V. Egorova, M. S. Egorov et al. Formation of interparticle splicing of hot-deformed powder steels obtained from alloyed powders// Blank production in mechanical engineering. - 2017. -T. 15. No. 6. C. 277-281.

5. R. V. Egorova, M. S. Egorov, V. N. Pustovoit, G. A. Biluk Kinetics of occurrence of cracks in cylindrical samples of okazyvaemsyall Vestnik of don state technical University. - 2017. -Vol. 17. No. 3 (90). P. 103-109.

6. M. S. Egorov, S. N. Egorov hot-Deformed powder low-alloy steels 